\title{
Penerapan Sanksi Pidana Terhadap Pengambilan Paksa Jenasah Pasien Covid-19 Di Indonesia
}

\section{Fadhil Yazid ${ }^{1, *}$}

${ }^{1}$ Fakultas Hukum Universitas Dharmawangsa, Medan

fadhilyazid.fh@dharmawangsa.ac.id ${ }^{1}$

*Corespondence Author

\begin{abstract}
Abstrak
Sehubungan dengan semakin meningkatnya jumlah kasus Covid-19 di Indonesia yang sampai dengan bulan Juli 2020 mencapai lebih dari 86 ribu kasus dimana terdapat lebih dari 4 ribu jiwa yang meninggal dunia. Kasus kematian akibat Covid-19 yang cukup tinggi tersebut menimbulkan gejolak di masyarakat. Kasus pengambilan paksa jenazah pasien Covid-19 terjadi di beberapa daerah di Indonesia. Dalam hal Maraknya kasus pengambilan paksa Jenazah Pasien Dalam Pengawasan (PDP) Covid-19 oleh pihak keluarga di berbagai daerah di Indonesia mendorong Kepolisian Republik Indonesia menerbitkan surat telegram Kapolri Nomor ST/1618/VI/Ops.2/2020 tanggal 5 Juni 2020. Surat Telegram tersebut ditujukan kepada para Kasatgas, Kasubsatgas, Kaopsda, dan Kaopsres Opspus Aman Nusa II 2020 untuk saling berkoordinasi dan bekerja sama dengan rumah sakit yang menjadi rujukan untuk penanganan pasien Covid-19 untuk segera melaksanakan tes swab terhadap pasien yang dirujuk, terutama pasien yang sudah menunjukkan gejala Covid-19, memiliki riwayat penyakit kronis, atau dalam keadaan kritis. Dengan berlakunya Surat Telegram tersebut memperbolehkan keluarga mengambil jenazah PDP Covid-19 dengan sejumlah syarat. Sehingga, apabila masih ada pihak yang melakukan pengambilan jenazah pasien PDP Covid-19 secara paksa dapat dikenakan sanksi pidana.
\end{abstract}




\title{
Kata Kunci : Sanksi Pidana, Pengambilan, Jenasah, Covid-19
}

Naskah dikirim: 21 Juli 2020|Direvisi : 18 Agustus 2020|Diterbitkan: 28 Agustus 2020

\begin{abstract}
In connection with the increasing number of Covid-19 cases in Indonesia, up to July 2020 there were more than 86 thousand cases in which there were more than 4 thousand people who died. Cases of death due to Covid-19 are quite high, causing turmoil in the community. Cases of forced collection of the bodies of Covid-19 patients occurred in several regions in Indonesia. In the case of the rampant case of forced collection of the bodies of patients under surveillance (PDP) Covid-19 by the family in various regions in Indonesia pushed the Indonesian National Police to issue a telegram letter from the National Police Chief Number ST / 1618 / VI / Ops.2 / 2020 on June 5. The Telegram letter was addressed to the Kasatgas, Kasubsatgas, Kaopsda, and the Opspus Aman Nusa II 2020 Kaopsres to coordinate with each other and cooperate with the hospitals that were referred for handling Covid-19 patients to immediately carry out swab tests on referred patients, especially patients who were referred have shown symptoms of Covid-19, have a history of chronic illness, or are in critical condition. With the enactment of the Telegram Letter allows families to take the body of PDP Covid-19 with a number of conditions. So, if there are still parties who take the corpses of PDP Covid-19 patients by force can be subject to criminal sanctions.
\end{abstract}

\section{Keywords: Criminal Sanctions, Collection, Bodies, Covid-19}

\section{Pendahuluan}

Covid-19 atau 2019-nCoV atau SARS-CoV-2, atau lebih dikenal dengan sebutan virus corona telah menjadi topik hangat pada awal tahun 2020. Virus corona ini diketahui sejak akhir Desember 2019 di Kota Wuhan, Provinsi Hubei, Negara Cina. Virus corona menyerang saluran pernafasan manusia dan sangat cepat menularkan kepada manusia yang lainnya.Virus corona ini sangat berbahaya dan telah menyebar ke seluruh dunia 
yang membuat World Health Organization (WHO) menetapkan status penularan virus corona ini sebagai pandemi. ${ }^{1}$

Di Indonesia, kasus Covid-19 cukup tinggi, dimana sampai dengan bulan Juli 2020, Indonesia berada di peringkat 25 dunia, negara yang terpapar Covid-19. Dimana sudah terdapat lebih dari 86 ribu kasus diantaranya terdapat lebih dari 4 ribu jiwa yang meninggal dunia akibat Covid-19. ${ }^{2}$ Kasus kematian akibat Covid-19 yang cukup tinggi tersebut menimbulkan gejolak di masyarakat, khususnya pihak keluarga Jenazah Pasien Dalam Pengawasan (PDP) Covid-19. Kasus pengambilan paksa jenazah pasien Covid-19 terjadi di beberapa daerah di Indonesia, diantaranya terjadi di Makassar. Pihak keluarga tidak terima jenazah kerabatnya dinyatakan positif Covid-19 dan mendesak rumah sakit memperlihatkan bukti hasil tes. Bahkan Kepolisian Daerah Sulawesi Selatan sudah menetapkan lebih dari 35 orang tersangka dalam kasus pengambilan paksa jenazah corona. $^{3}$

Kemudian, kasus serupa juga terjadi di salah satu rumah sakit (RS) rujukan corona di Bekasi Timur, yang dijemput paksa oleh keluarganya. Lalu, di Kabupaten Penukal Abab Lematang Ilir, terjadi peristiwa jatuhnya jenazah hingga keluar dari peti pada proses pemakaman menggunakan protokol Covid-19. Kejadian tersebut menyebabkan protes dari pihak keluarga. Apalagi, pihak keluarga juga keberatan dengan proses pemakaman yang menggunakan protokol Covid-19 sebab belum dilakukan tes swab terhadap pasien. Daerah lain yang juga terdapat kasus pengambilan paksa jenazah pasien Covid-19 yaitu Surabaya, Mataram, Manado, Pamekasan, hingga Ambon.

Kepolisian Republik Indonesia sudah menyatakan bahwasannya kasus pengambilan paksa jenazah yang dinyatakan positif Covid-19 tersebut adalah melanggar aturan peraturan perundang-undangan yang berlaku karena akan membahayakan banyak

\footnotetext{
${ }^{1}$ https://sains.kompas.com/read/2020/02/19/171500923/nama-virus-corona-wuhan sekarang-sars-cov-2-ini-bedanya-dengan-covid-19?page=all, diakses pada tanggal 21 Juli 2020

${ }^{2} \mathrm{https}: / /$ www.bbc.com/indonesia/indonesia-53479645, diakses pada tanggal 21 Juli 2020

${ }^{3}$ Susilo, A. (2020). Coronavirus Disease 2019: Tinjauan Literatur Terkini. Jurnal Penyakit Dalam Indonesia, Universitas Indonesia, Volume 7 Nomor 1, Hal 45. DOI : https://doi.org/10.7454/jpdi.v7i1.415
} 
pihak, dan hal ini merupakan tindak pidana. Bahkan sudah banyak pihak yang dijadikan tersangka oleh Kepolisian Republik Indonesia. Pihak Kepolisian Republik Indonesia juga sudah mengeluarkan peraturan atau instruksi untuk menyelesaikan kasus pengambilan paksa jenazah pasien Covid-19 yaitu dengan menerbitkan surat telegram Kapolri Nomor ST/1618/VI/Ops.2/2020. Diperlukan tindakan tegas terhadap pihak yang masih melakukan pengambilan paksa jenazah pasien Covid-19. Sehingga juga diperlukan keterlibatandari tokoh-tokoh agama, masyarakat, budayawan, sosiolog, antropolog, untuk melakukan komunikasi maupun memberikan pemahaman kepada masyarakat agar jangan sampai terjadi lagi kasus pengambilan paksa jenazah Covid-19.

\section{Pembahasan}

\section{Implementasi Telegram Kapolri No.ST/1618/VI/OPS.2/2020 Tanggal 5 Juni 2020}

Dalam hal Maraknya kasus pengambilan paksa Jenazah Pasien Dalam Pengawasan (PDP) Covid-19/ virus corona oleh pihak keluarga di berbagai daerah di Indonesia mendorong Kepolisian Republik Indonesia menerbitkan surat telegram Kapolri Nomor ST/1618/VI/Ops.2/2020 tanggal 5 Juni. ${ }^{4}$ Surat Telegram tersebut ditujukan kepada para Kasatgas, Kasubsatgas, Kaopsda, dan Kaopsres Opspus Aman Nusa II 2020 untuk saling berkoordinasi dan bekerja sama dengan rumah sakit yang menjadi rujukan untuk penanganan pasien Covid-19 untuk segera melaksanakan tes swab terhadap pasien yang dirujuk, terutama pasien yang sudah menunjukkan gejala Covid-19, memiliki riwayat penyakit kronis, atau dalam keadaan kritis. Selain itu, Surat Telegram tersebut juga memerintahkan para Kasatgas, Kasubsatgas, Kaopsda (Kapolda), dan Kaopsres (Kapolres) Opspus Aman Nusa II 2020 untuk berkoordinasi dan bekerja sama dengan pihak rumah sakit rujukan Covid-19 untuk memastikan penyebab kematian pasien apakah benar-benar korban Covid-19 atau tidak.

${ }^{4}$ https://www.viva.co.id/ragam/round-up/1278741-ironi-pengambilan-paksa-jenazahcorona, diakses pada tanggal 21 Juli 2020 
Jika jenazah yang dimaksud telah dipastikan positif Covid-19, maka proses pemakamannya harus dilakukan sesuai prosedur Covid-19. Tes swab tersebut harus dilakukan agar pasien bisa mengetahui positif atau negatif terinfeksi Covid-19. Dengan demikian, tidak akan timbul keraguan dari pihak keluarga kepada rumah sakit dalam proses penanganan pasien.

Ketika suatu masalah hukum yang baru muntul maka harus dilakukan kebijakan aplikatif sambil menunggu kebijakan formasi yang dilakukan. Dengan berlakunya Surat Telegram nomor ST/1618/VI/Ops.2/2020 tersebut yang memperbolehkan keluarga mengambil jenazah PDP Covid-19 dengan sejumlah syarat dapat menenangkan kekhawatiran masyarakat. Hal ini tentunya diharapkan bisa menjawab keresahan warga yang baru saja kehilangan anggota keluarganya karena corona, maupun masyarakat pada umumnya. ${ }^{5}$

Syarat pengambilan jenazah PDP Covid-19 tersebut yaitu : adanya surat keterangan pemeriksaan Polymerase Chain Reaction (PCR) yang dinyatakan negatif. Setelah dinyatakan meninggal dunia, keluarga jenazah harus menunggu selama lebih kurang 4-5 jam, untuk dilakukannya pemeriksaan terlebih dahulu. ${ }^{6}$

Dalam hal penanganan jenazah PDP Covid-19, hal yang harus diperhatikan adalah apabila Jika jenazah yang dimaksud telah dipastikan positif Covid-19, maka proses pemakamannya harus dilakukan sesuai prosedur Covid-19. Namun jika jenazah terbukti negatif Covid-19, maka proses pemakamannya dapat dilakukan sesuai dengan syariat atau ketentuan agamanya masing-masing. Kendati demikian, himbauan kepada pihak keluarga agar proses persemayaman dan pemakamannya tetap menerapkan protokol kesehatan, mulai dari memakai masker hingga berjaga jarak.

\section{Pertanggung Jawaban Negara Terhadap Biaya Pasien Covid-19}

5 Lokollo, L., Salamor, Y. B., \& Ubwarin, E. (2020). Kebijakan Formulasi Undang-undang Narkotika Dalam Legalisasi Penggunaan Ganja Sebagai BahanPengobatan di Indonesia. Jurnal Belo, Volume 5 Nomor 2. DOI: https://doi.org/10.30598/belovol5issue2page1-20

${ }^{6}$ https://medan.tribunnews.com/2020/06/12/tim-gugus-tugas-buat-aturan-baru-jenzah-pdpcovid-19-boleh-dimakamkan-oleh-keluarga, diakses pada tanggal 21 Juli 2020

DOI: https://doi.org/10.30598/belovol6issue1page60-72 Copyright (c) 2020 Author 
Jika terjadi sebuah masalah hukum yang mucul dan mengakibatkan seseorang mengalami kerugian maka harus dilakukan rehabilitasi baik pengantian biaya maupun pemulihan psikologis. ${ }^{7}$ Dalam Keputusan Presiden Nomor 12 Tahun 2020 tentang Penetapan Bencana Non-alam Penyebaran Corona Virus Disease 2019 (Covid-19) Sebagai Bencana Nasional, bencana non-alam yang diakibatkan oleh penyebaran Covid19 ditetapkan sebagai bencana nasional. Sehingga, menurut ketentuan Pasal 82 UndangUndang Nomor 36 Tahun 2009 tentang Kesehatan yang mengatur soal pelayanan kesehatan pada waktu bencana, bahwa pemerintah pusat, pemerintah daerah, dan masyarakat bertanggung jawab atas ketersediaan sumber daya, fasilitas, dan pelaksanaan pelayanan kesehatan secara menyeluruh dan berkesinambungan pada bencana. ${ }^{8}$

Pemerintah menjamin pembiayaan pelayanan kesehatan yang bersumber dari anggaran pendapatan dan belanja negara, anggaran pendapatan dan belanja daerah, atau bantuan masyarakat sesuai peraturan perundang-undangan. Selain itu, dalam Pasal 5 ayat (1) huruf b Undang-Undang Nomor 4 Tahun 1984 tentang Wabah Penyakit Menular, ditegaskan bahwa salah satu upaya penanggulangan wabah adalah pemeriksaan, pengobatan, perawatan, dan isolasi penderita, termasuk tindakan karantina.

Upaya tersebut merupakan tanggung jawab pemerintah. Semua biaya yang timbul dalam upaya penanggulangan wabah dibebankan pada anggaran instansi masing-masing yang terkait sebagaimana diterangkan Pasal 30 ayat (1) Peraturan Pemerintah Nomor 40 Tahun 1991 tentang Penanggulangan Wabah Penyakit Menular. Sehingga dalam hal ini, pemerintah juga turut bertanggung jawab dalam penyediaan alat kesehatan dan alat pelindung diri (APD) dalam rangka melaksanakan pelayanan kesehatan untuk menanggulangi penyebaran Covid-19.

7 Mawati, E., Takariawan, A., \& Sulistiani, L. (2020). Kebijakan Hukum Pidana Mengenai Rehabilitasi Psikososial Korban Tindak Pidana Terorisme Dalam Sistem Peradilan Pidana. Jurnal Belo, Volume 5, Nomor 2, 34-56. DOI : https://doi.org/10.30598/belovol5issue2page34-56

${ }^{8}$ https://www.hukumonline.com/klinik/detail/ulasan/lt5e97e97edfbda/hak-hak-pasientenaga-kesehatan-dan-dokter-di-tengah-wabah-covid-19/, diakses pada tanggal 21 Juli 2020 
Berdasarkan Keputusan Menteri Kesehatan Nomor : HK.01.07/MENKES 104/104/2020, bagi pasien yang diduga tertular virus corona, biaya penanganan pasien bisa langsung ditanggung dari rumah sakit rujukan yang sudah ditetapkan Kementerian Kesehatan. Dalam hal ini ditegaskan bahwa biaya perawatan yang terkait kasus Covid-19 akan ditanggung negara sejak pasien ditetapkan sebagai orang dalam pemantauan (ODP). Status ODP adalah status paling awal, sebelum naik ke pasien dalam pengawasan (PDP), suspect, dan positif Covid-19. Baik itu ODP, PDP dan suspect semua biayanya ditanggung oleh negara, tetapi sepanjang terkait dengan kasus Covid-19.

Adapun perbedaan ODP, PDP dan suspect. yaitu, orang yang berstatus ODP belum menunjukkan gejala sakit. Namun orang di kategori ini sempat bepergian ke negara episentrum corona atau sempat melakukan kontak dengan pasien positif corona. Sementara PDP adalah orang yang sudah menunjukkan gejala terjangkit Covid-19 seperti demam, batuk, pilek dan sesak napas. Adapun suspect adalah orang yang sudah menunjukkan gejala corona dan juga diduga kuat sudah melakukan kontak dengan pasien positif corona. ${ }^{9}$ Begitu dinyatakan suspect, dilakukan pemeriksaan (spesimen), confirm enggak. Kalau confirm, positif Covid-19. Adapun hak-hak pasien Covid-19, secara umum telah diatur dalam Pasal 32 Undang-Undang Nomor 44 Tahun 2009 tentang Rumah Sakit.

Mengeluarkan peraturan perundang-undangan sangat penting untuk mengatur sebuah masyarakat yang mengalami kekosongan hukum. ${ }^{10}$ Pemerintah melalui Kementerian Kesehatan pada 24 April 2020 telah menerbitkan Surat Edaran Nomor HK.02.01/Menkes/295/2020 yang mengatur klaim penggantian biaya perawatan pasien Covid-19 oleh rumah sakit. Klaim tersebut merujuk kepada ketentuan yang berlaku di dalam Keputusan Menteri Kesehatan Nomor HK.01.07/Menkes/238/2020 tentang Petunjuk Teknis Klaim Penggantian Biaya Perawatan Pasien Penyakit Infeksi Emerging

\footnotetext{
${ }^{9}$ https://jabarprov.go.id/index.php/news/37107/2020/03/20/Perbedaan-ODP-PDP-

Suspect-dan-Positif, diakses pada tanggal 21 Juli 2020

${ }^{10}$ Latukau, F. (2020). Pengadopsian UNCAC Mengenai Pengembalian Aset Hasil Korupsi Yang Dibawa Atau Disimpan Ke Luar Negeri Dalam Penegakan Hukum Indonesia. Jurnal Belo, Volume 5 Nomor 1. DOI: https://doi.org/10.30598/belovol5issue1page10-31
} 
Tertentu bagi Rumah Sakit yang Menyelenggarakan Pelayanan Covid-19. Biaya perawatan seluruh pasien Covid-19 di Indonesia dibebankan pada anggaran Badan Nasional Penanggulan Bencana (BNPB). Jika pasien telanjur membayar, rumah sakit harus mengembalikan ke pasien.

Adapun cara mengajukan klaim perawatan rumah sakit pasien Covid-19 harus memperhatikan beberapa hal berikut ini sesuai dengan Kepmenkes No.HK.01.07/238/2020, yaitu: ${ }^{11}$

1) Pengajuan klaim biaya perawatan pasien Covid-19 dapat diajukan oleh rumah sakit rujukan dan rumah sakit lain secara kolektif kepada Direktur Jenderal Pelayanan Kesehatan cq. Direktur Pelayanan Kesehatan Rujukan Kementerian Kesehatan ditembuskan ke BPJS Kesehatan untuk verifikasi dan Dinas Kesehatan Daerah Kabupaten/Kota melalui email.

2) Berkas klaim penggantian biaya perawatan pasien Covid-19 yang dapat diajukan oleh rumah sakit adalah untuk pasien yang dirawat sejak 28 Januari 2020.

3) Berkas klaim yang diajukan rumah sakit dalam bentuk soft copy hasil scanning/foto berkas klaim (berkas klaim hard copy disimpan di rumah sakit) untuk di-upload secara online.

4) Pengajuan klaim dapat diajukan oleh rumah sakit setiap 14 hari kerja.

5) BPJS Kesehatan mengeluarkan berita acara verifikasi pembayaran klaim tagihan pelayanan paling lambat tujuh hari kerja sejak klaim diterima oleh BPJS Kesehatan.

6) Kementerian Kesehatan akan membayar ke rumah sakit dalam waktu tiga hari kerja setelah diterimanya berita acara hasil verifikasi klaim dari BPJS Kesehatan.

7) Kasus dispute akan dilakukan klarifikasi dan verifikasi ulang.

\footnotetext{
${ }^{11}$ https://covid19.kemkes.go.id/situasi-infeksi-emerging/info-corona-virus/begini-teknisrs-klaim-biaya-perawatan-pasien-covid-19/\#.XxbHs-eyTIU, diakses pada tanggal 21 Juli 2020 


\section{Sanksi Hukum Bagi Yang Melanggar Implementasi Kapolri No.ST/1618/VI/ OPS.2/2020 Tanggal 5 Juni 2020}

Hukum tidak boleh terlambat dengan perkembagan masyarakat, karena jika terlabat maka akan sulit untuk meminta pertanggungjawaban pidana kepada pelaku tindak pidana. ${ }^{12}$ Fenomena jenazah pasien dalam pengawasan (PDP) terkait virus corona Covid-19 diambil paksa anggota keluarganya marak terjadi di Indonesia. Tragisnya, tak sedikit jenazah PDP yang akhirnya dinyatakan positif Covid-19 setelah hasil tes swabnya keluar. Sementara pihak keluarga tidak memakamkan jenazah tersebut sesuaiprotokol kesehatan pencegahan Covid-19.

Penegakan hukum harus dilakukan kepada semua orang yang melakukan tindak pidana. ${ }^{13}$ Dengan adanya kasus pengambilan paksa jenazah pasien PDP Covid-19 oleh pihak keluarga tersebut maka kepolisian Republik Indonesia meminta agar tes swab pasien dipercepat, instruksi tersebut dituangkan dalam Surat Telegram Kapolri Nomor ST/1618/ VI/Ops.2/2020 tanggal 5 Juni 2020.

Pihak Kepolisian Republik Indonesia juga sudah menyatakan bahwasannya apabila ada pihak yang melakukan pengambilan paksa jenazah pasien Covid-19 tidak sesuai prosedur yang berlaku, maka dapat dikenakan sanksi pidana. Bahkan sudah cukup banyak pihak yang dijadikan tersangka dalam kasus tersebut. Penetapan tersangka oleh pihak kepolisian tersebut salah satunya bertujuan untuk mencegah terjadinya kembali kasus pengambilan paksa jenazah pasien Covid-19 oleh pihak keluarga.

Koeswadji menjelaskan tujuan pokok dilakukannya pemidanaan yaitu:

1) Untuk mempertahankan ketertiban dalam kehidupan bermasyarakat;

2) Untuk memperbaiki kerugian yang diderita oleh masyarakat sebagai akibat dari terjadinya kejahatan;

3) Untuk memperbaiki pelaku kejahatan;

12 Ubwarin, E., \& Corputty, P. (2020). Pertangungjawaban Pidana Dalam Keadaan Darurat Bencana Covid-19. Mizan: Jurnal Ilmu Hukum, Volume 9 Nomor 1. Hal 6. DOI : https://doi.org/10.32503/mizan.v9i1.1043

13 Fadillah A. N., 'M. I. A. A. (2020). Optimalisasi Penegakan Hukum Pidana Terhadap Tindak Pidana Perikanan (Studi Perbandingan Hukum Pidana Di Bidang Perikanan). Sasi, Volume 26 Nomor 2. DOI : https://doi.org/10.47268/sasi.v26i2.280 
4) Untuk membinasakan pelaku kejahatan;

5) Untuk mencegahterjadinya kejahatan. ${ }^{14}$

Menurut Sholehuddin tujuan diberikannya sanksi pidana yaitu:

1) Untuk memberikan efek penjeraan dan penangkalan. Penjeraan disini berarti menjauhkan pelaku pidana dari kemungkinan mengulangi kejahatan yang sama. Penangkalan bertujuan untuk mengingatkan dan menakuti penjahat yang berpotensial di masyarakat agar tidak melakukan kejahatan.

2) Untuk memberikan rehabilitasi. Pemidanaan adalah sebagai jalan untuk mencapai reformasi atau rehabilitasi pada pelaku pidana. Pemidanaan merupakan proses pengobatan sosial dan moral bagi seorang terpidana agar kembali berintegrasi dalam masyarakat secara wajar.

3) Pemidanaan dilakukan sebagai wahana pendidikan moral, atau merupakan proses reformasi. Karena itu dalam proses pemidanaan, pelaku pidana dibantu untuk menyadari dan mengakui kesalahan yang dituduhkan kepadanya. ${ }^{15}$

Sehingga dengan adanya surat telegram Kapolri tersebut, apabila masih ada pihak yang melakukan pengambilan jenazah pasien PDP Covid-19 secara paksa dapat dikenakan sanksi pidana. Dasarnya ialah Pasal 5 Undang-Undang Nomor 4 Tahun 1984 tentang Wabah Penyakit Menular dengan ancaman satu tahun penjara atau denda hingga Rp.100.000.000 (Seratus Juta Rupiah) seperti diatur pada Pasal 93 Undang-Undang Nomor 6 Tahun 2018 tentang Kekarantinaan Kesehatan. Selain itu pihak yang mengambil jenazah PDP pasien Covid-19 secara paksa juga dapat dikenakan Pasal berlapis yaitu Pasal 214 KUHP joPasal 335 KUHP jo. Pasal 336 KUHP jo. Pasal 93 Undang-Undang Nomor 6 Tahun 2018, dengan ancaman hukuman sampai dengan 7 (tujuh) tahun.

\section{Penutup}

Kepolisian Republik Indonesia menerbitkan surat telegram Kapolri Nomor ST/1618/VI/Ops.2/2020 tanggal 5 Juni sebagai pedoman untuk menyelesaikan maraknya

\footnotetext{
${ }^{14}$ Koeswadji, Perkembangan Macam-Macam Pidana Dalam Rangka Pembangunan Hukum Pidana, Citra Aditya Bhakti, Bandung, 1995, hal. 21

${ }^{15}$ Sholehuddin, Sistem Sanksi Dalam Hukum Pidana, Ide Dasar Double Track System dan Implementasinya, Raja Grafindo, Jakarta, 2003, hal. 49
}

DOI: https://doi.org/10.30598/belovol6issue1page60-72 
kasus pengambilan paksa Jenazah Pasien Dalam Pengawasan (PDP) Covid-19 di berbagai daerah di Indonesia. Surat Telegram tersebut ditujukan kepada para Kasatgas, Kasubsatgas, Kaopsda, dan Kaopsres Opspus Aman Nusa II 2020 untuk saling berkoordinasi dan bekerja sama dengan rumah sakit yang menjadi rujukan untuk penanganan pasien Covid-19 untuk segera melaksanakan tes swab terhadap pasien yang dirujuk, terutama pasien yang sudah menunjukkan gejala Covid-19, memiliki riwayat penyakit kronis, atau dalam keadaan kritis. Syarat pengambilan jenazah PDP Covid-19 tersebut yaitu : adanya surat keterangan pemeriksaan Polymerase Chain Reaction (PCR) yang dinyatakan negatif. Setelah dinyatakan meninggal dunia, keluarga jenazah harus menunggu selama lebih kurang 4-5 jam, untuk dilakukannya pemeriksaan terlebih dahulu. Apabila ada pihak yang melakukan pengambilan jenazah pasien PDP Covid-19 secara paksa dapat dikenakan sanksi pidana.

\section{Daftar Pustaka}

\section{Jurnal}

[1] Latukau, F. (2020). Pengadopsian UNCAC Mengenai Pengembalian Aset Hasil Korupsi Yang Dibawa Atau Disimpan Ke Luar Negeri Dalam Penegakan Hukum Indonesia. Jurnal Belo, Volume 5 Nomor 1. DOI: https://doi.org/10.30598/belovol5issue1page10-31

[2] Lokollo, L., Salamor, Y. B., \& Ubwarin, E. (2020). Kebijakan Formulasi Undang-undang Narkotika Dalam Legalisasi Penggunaan Ganja Sebagai BahanPengobatan di Indonesia. Jurnal Belo, Volume 5 Nomor 2. DOI: https://doi.org/10.30598/belovol5issue2page1-20

[3] Mawati, E., Takariawan, A., \& Sulistiani, L. (2020). Kebijakan Hukum Pidana Mengenai Rehabilitasi Psikososial Korban Tindak Pidana Terorisme Dalam Sistem Peradilan Pidana. Jurnal Belo, Volume 5, Nomor 2, 34-56. DOI : https://doi.org/10.30598/belovol5issue2page34-56 
[4] Susilo, A. (2020). Coronavirus Disease 2019: Tinjauan Literatur Terkini. Jurnal Penyakit Dalam Indonesia, Universitas Indonesia, Volume 7 Nomor 1, Hal 45. DOI : https://doi.org/10.7454/jpdi.v7i1.415

[5] Ubwarin, E., \& Corputty, P. (2020). Pertangungjawaban Pidana Dalam Keadaan Darurat Bencana Covid-19. Mizan: Jurnal Ilmu Hukum, Volume 9 Nomor 1. Hal 6. DOI : https://doi.org/10.32503/mizan.v9i1.1043

[6] Fadillah A. N., 'M. I. A. A. (2020). Optimalisasi Penegakan Hukum Pidana Terhadap Tindak Pidana Perikanan (Studi Perbandingan Hukum Pidana Di Bidang Perikanan). Sasi, Volume 26 Nomor 2. DOI : https://doi.org/10.47268/sasi.v26i2.280

\section{Buku}

[7] E Koeswadji. (1995). Perkembangan Macam-Macam Pidana Dalam Rangka Pembangunan Hukum Pidana, Citra Aditya Bhakti, Bandung.

[8] Sholehuddin. (2003). Sistem Sanksi Dalam Hukum Pidana, Ide Dasar Double Track System dan Implementasinya, Raja Grafindo, Jakarta.

\section{Lain-lain}

[9] https://sains.kompas.com/read/2020/02/19/171500923/nama-virus-coronawuhan sekarang-sars-cov-2-ini-bedanya-dengan-covid-19?page=all, diakses pada tanggal 21 Juli 2020

[10] https://www.bbc.com/indonesia/indonesia-53479645, diakses pada tanggal 21 Juli 2020

[11] https://www.viva.co.id/ragam/round-up/1278741-ironi-pengambilan-paksajenazah-corona, diakses pada tanggal 21 Juli 2020

[12] https://medan.tribunnews.com/2020/06/12/tim-gugus-tugas-buat-aturan-barujenzah-pdp-covid-19-boleh-dimakamkan-oleh-keluarga, diakses pada tanggal 21 Juli 2020 
[13] https://www.hukumonline.com/klinik/detail/ulasan/lt5e97e97edfbda/hak-hakpasien-tenaga-kesehatan-dan-dokter-di-tengah-wabah-covid-19/, diakses pada tanggal 21 Juli 2020

[14] https://jabarprov.go.id/index.php/news/37107/2020/03/20/Perbedaan-ODP-PDPSuspect-dan-Positif, diakses pada tanggal 21 Juli 2020

[15] https://www.cnnindonesia.com/ekonomi/20200619172653-532-515291/srimulyani-sebut-dana-penanganan-corona-naik-jadi-rp905-t, diakses 16 Juli 2020

[16] https://bogor.pikiran-rakyat.com/nasional/pr-08598052/polri-kantongi-55-kasusdugaan-penyelewengan-dana-bansos-covid-19-motifnya-potongan-bantuan , diakses 16 Juli 2020 